\title{
The Failure of Providing Human Security for Rohingya Refugees (Case Study: Escaping Rohingya Refugees from Shelter In SKB Bireuen, Aceh Province)
}

\author{
Risky Novialdi ${ }^{1}$, Chairul Bariah ${ }^{2}$, Zahraini ${ }^{3}$ \\ ${ }^{1}$ Al Muslim University, Bireuen, Aceh Province, Indonesia \\ ${ }^{2}$ Al Muslim University, Bireuen, Aceh Province, Indonesia \\ ${ }^{3}$ Al Muslim University, Bireuen, Aceh Province, Indonesia \\ Hera.aldyra@gmail.com
}

\begin{abstract}
This paper analyses the failure to provide humanitarian security for Rohingya refugees at the Sanggar Kegiatan Bersama (SKB) in Bireuen, Aceh. Humanitarian protection should provide security and comfort for Rohingya refugees. Aceh province has several times provided protection for Rohingya refugees, but it did not last long, Rohingya refugees often escape from shelters. This means that Aceh has failed to provide human security for Rohingya refugees. What exactly caused this failure? While Aceh has provided human security in a political context, it has been unable to provide human security in an economic sense. In addition, there have been allegations that Rohingya refugees in Aceh are not only seeking asylum but also trying to find work. From initial observation until 15 April 2019, only two people were still living in the SKB as refugees. The other refugees had escaped from the shelter. This paper draws on interviews and direct observation at the Bireuen SKB.
\end{abstract}

Keywords: Human Security, Rohingya Refugees, Bireuen, Aceh.

\section{INTRODUCTION}

The humanitarian crisis that befell the Rohingya is not a secret. News about ethnic cleansing carried out by the Myanmar government against the Rohingya nation has spread throughout the world through mass media and social media. Burma has committed violationsof 'first generation' human right (as codified in the 1948 Universal Declaration of Human Rights) and 'secoud generation' economic, social dan political rights (Srikandini, 2011, p. 19). Violations against humanity continue in Myanmar to the Rohingyas in the Rakhine area. According to the Amnesty International, Rohingya Muslims continue to suffer human rights abuses under Myanmar's military junta since 1978, and many have fled to Bangladesh. More than 671,000 Rohingya Muslims have fled Burma's Rakhine State since late August 2017 to escape the military's large-scale campaign of ethnic cleansing. The violations committed by Burmese security forces include mass killings, sexual violence, and widespread arson which amount to crimes against humanity. Military and civilian officials have repeatedly denied that security forces committed the mentioned violations during the operations, claims which are contradicted by extensive evidence and witness accounts (Human Rights Watch, n.d.). In 2018, it was reported that the conflict in Rakhine had subsided and even the Rohingyas who had taken refuge were allowed to return to Myanmar, but it turned out that a wave of refugees was still happening. The most recent was the seizure of 79 Rohingya at Kuala Raja Beach, Bireuen, Aceh Province in April last year (Sofinar, 2018). 
Rohingya refugees are still seeking protection from ethnic cleansing that have occurred in Myanmar. According to UNHCR, there are 36,290 Rohingya refugees seeking refuge in Malaysia as of April 2014. It is stated the Malaysian government frequently detains the refugees and asylum-seekers for months in immigration camps in where they suffer from malnutrition, unsanitary conditions and beatings. The refugees are often moved towards the border of Malaysia-Thailand; their entry point to Malaysia. The Rohingyas continue to face vulnerabilities towards harassment and confinement, as they do not have proper legal mechanism to ensure their safety. Likewise, they are forbidden to work in Malaysia even if they hold UNHCR documents, which forced them to work illegally. Despite their poor living conditions in Malaysia, they still refuse to return to Myanmar due to the knowledge of their destroyed homes and fear of violence.

Aceh Province (Indonesia) is one of the regions that tries to provide security protection for Rohingya refugees. Based on the data from UNHCR World Refugee Agency, as of 2016 there were 795 Rohingya refugees in Indonesia. Then, there are 244 who are still waiting for the determination of status or in other words are asylum seekers. The majority of them are in Indonesia after navigating the sea with makeshift ships.Rohingya refugees in Bireuen District, are accommodated in Sanggar Kegiatan Bersama (SKB), all needs are fulfilled because of assistance from local, national and even international parties through the Social Service, Badan Penanggulangan Bencana Daerah Bireuen (BPBD or Bireuen Regional Disaster Management Agency), and Tenaga Kesejahteraan Sosial Kecamatan ( TKSK or District Social Workers), Palang Merah Indonesia (PMI or Indonesian Red Cross), and Front Pembela Islam (FPI or Islamic Defenders Front ), Aksi Cepat Tanggap (ACT), the United Nations High Commissioner for Refugees (UNHCR) and The International Organization of Migration (IOM).

However, the current number of refugees is decreasing, as stated on the local newspaper (Serambi), there are only 11 Rohingya refugees remaining as of February 2019. After carrying out preliminary observations in April 2019, there were only 2 refugees in the SKB. From this incident, it can be understood that there were serious problems that occurred in the Rohingya refugee shelter. The shelter plan was initially planned to protect humanitarian security for Rohingya refugees, however, the events of escaping Rohingya refugees from the shelter showed that there were problems in providing human security.

From initial observation until 15 April 2019, only two people were still living in the SKB as refugees. The other refugees had escaped from the shelter. This incident certainly confused the international community, as to what caused them to flee the shelter since previous exchange of information indicated good treatment of the Rohingya. Is the humanitarian security provided by Aceh Province still inadequate? It is an important question that we will try to elaborate in this paper. Humanitarianism is almost always controversial-resource distribution in the midst of armed conflicts may alter the balance among belligerents and strenghtens the hand of those who distrubute it. Humanitarian action is viewed not only through prisms of ethics and power but also those of politics or distribute consequences.

From the above problems, this paper will analyze what really happened to make the provision of humanitarian security protection against Rohingya refugees experience 
problems (fail), which eventually resulted in most of them escaping from the shelter. This paper will also reveal facts about the main motives behind the arrival of Rohingya refugees to Aceh. To strengthen the data that will be presented in this paper, direct observation and interviews will be conducted with those involved in providing humanitarian security for Rohingya refugees in Bireuen district.

\section{RESEARCH METHOD}

This reseach uses qualitative method, by gathering previous studies through observation, interviews and data collection from books, journals, news in newspapers and websites. Leedy and Ormrod (2013) in Juminah (2018) states that researchers of qualitative focus tend to construct and interpret their own understanding from collected data and try to grasp the complexity of the case. Qualitative researchers thus use a more personal, literary style, and they often include the participant's language. The data obtained will be analyzed to obtain facts about the cause of the failure of the Bireuen's government in providing Humanitarian Security for Rohingya refugees, and finally they escaped from the shelter.

\section{THEORETICAL FRAMEWORK}

\section{HUMAN SECURITY}

To analyze the case regarding handling Rohingya refugees in Bireuen District, we will use the concept of Human Security. The CHS, in its final report Human Security Now, defines human security as: "...to protect the vital core of all human lives in ways that enhance human freedoms and human fulfillment. Human security means protecting fundamental freedoms - freedoms that are the essence of life. It means protecting people from critical (severe) and pervasive (widespread) threats and situations. It means using processes that build on people's strengths and aspirations. It means creating political, social, environmental, economic, military and cultural systems that together give people the building blocks of survival, livelihood and dignity."

The late Dr Mahbub UI Haq first drew global attention to the concept of human security in the UNDP's Human Development Reports. In 1994, the Human Development Report focused explicitly on human security and argued that, in the author's understanding, the concept of security has been limited to traditional sectors such as conflicts and threats between states. Contrastingly, other insecurities such as job security, income security, health security, environmental security, security from crime are the emerging concerns that affects the entire humankind daily (Thomas, 2001).

The idea of human security is indeed more evident in the UNDP Report on the Human Development Report of the United Nations Development Program in 1994. The UNDP stated that the concept of security should transform from the overly-stressed national security to people-centric approach of security, which includes both aspects of armaments and human development (Fitrah, 2015). According to the 1994 UNDP Report, there are seven components of human security whose fulfillment must be the responsibility of each country's government. The seven components are economic security, food security, health security, environment security, personal security, community security, and political security (Oscar A. Gómez \& Gasper, 1994, p. 2). The 
seven components above can be simplified into two main components, namely freedom from fear (freedom from fear) and freedom from want (free from the inability in owning).

Table 1. Possible Types of Human Security Threats

\begin{tabular}{|c|c|}
\hline Type of Security & Examples of Main Threats \\
\hline Economic security & Persistent poverty, unemployment \\
\hline Food security & Hunger, famine \\
\hline Health security & $\begin{array}{c}\text { Deadly infectious diseases, unsafe food, } \\
\text { malnutrition, lack of } \\
\text { access to basic health care }\end{array}$ \\
\hline Environmental security & $\begin{array}{c}\text { Environmental degradation, resource } \\
\text { depletion, natural } \\
\text { disasters, pollution }\end{array}$ \\
\hline Political security & $\begin{array}{c}\text { Physical violence, crime, terrorism, } \\
\text { domestic violence, child labor }\end{array}$ \\
\hline Community security & $\begin{array}{c}\text { Inter-ethnic, religious and other identity } \\
\text { based tensions }\end{array}$ \\
\hline
\end{tabular}

Source: United Nations Trust Fund for Human Security, 2009 (Bello, 2016, pp. 154-155)

In the past two decades, the world has witnessed the demographic mega-trend of urbanization. People all over the world are moving from rural areas into cities to acces job, business system, housing, services and social opportunities in a centralized place. Refugess are amongst them and their decision to take exile in cities as opposed to camps, as was the previous patterrn, has required humanitarian agencies to reassess how to provide assistance and protection, especially to provide human security (Morand, 2015, p. 417). 
Humanitarian security is very important for refugees, such as Rohingya refugees who experience torture and discrimination from their country, Myanmar. The Rohingyas depart from Myanmar to seek protection and security from other countries. However, an interesting fact was explained by the committee of refugee shelters at the SKB Bireuen, that Rohingya Refugees left Myanmar to seek new life. Rohingya refugees do not want to return to Myanmar.

The information conveyed by the refugee handling committee shows that the government must think of something more long-term, not only concerning emergency matters such as clothing and shelter, but also social matters that will occur due to the arrival of these refugees. Politic in human affairs arises whenever there is a difference over an outcome sought by two or more independent actor -individual human or their agent- with respect to their disputed interests, aim, and values.

\section{THE CONCEPT OF PROTECTION}

Helton notes, the "concept of "protection" ... can be taken to mean the act of respecting and upholding fundamental human rights, such as the core rights declared in the Covenants on Civil and Political Rights, and on Economic, Social and Cultural Rights" (Helton, 2003).

The 1994 Note on International Protection is especially useful and helpful in showing how UNHCR perceived the broadening of its mandate and turn towards humanitarian aspect, especially to the extent of how protection is concerned. The note explains the adoption and usage of regional instruments such as the OAU Refugee Convention and the Cartagena Declaration, by broadening the usage of the term "refugee" to indicate people that require international protection due to severe fear for their well-being (life, liberty and security) in their home countries as a consequence of mistreatment, war or public disorder (United Nations General Assembly (UNGA), 1994). In this context, international organizations have an obligation to provide protection to Rogingya refugees, who have experienced violence in their country, Myanmar.

The materials of the Reach Out Refugee Protection Training Project (an initiative between NGOs, Red Cross/Red Crescent and the UNHCR to train humanitarian staff in the basic elements of refugee protection) provided the following UNHCR "working definition" (quoted from 'Designing Protection Strategies and Measuring Progress: Checklist for UNHCR Staff', Department of International Protection, Office of the United Nations High Commissioner for Refugees) of protection that strives to be comprehensible and comprehensive: "Protection encompasses all activities aimed at ensuring the enjoyment, on equal terms of the rights of women, men, girls and boys of concern to the UNHCR in accordance with the letter and spirit of the relevant bodies of law (international, humanitarian, human rights and refugee law). It includes interventions by States or UNHCR on behalf of asylum-seekers and refugees to ensure that their rights, security, and welfare are recognized and safeguarded in accordance with international standards. Such interventions will, amongst others, be deemed to: ensuring [sic] respect for the principle of nonrefoulement; promoting admission to safety and access to fair procedures for the determination of refugee status; upholding humane standards of treatment; realizing the right to assistance and services; promoting non-discrimination, and the 
implementation of durable solutions" (Reach Out Refugee Protection Training Project, 2005, p. 39).

Based on the explanation of the concept of "protection" above, especially the protection by international organizations against refugees, in this paper, we will look at the role of international organizations (UNHCR and IOM) in providing the protection of Rohingya refugees.

\section{RESULT AND DISCUSSION}

\section{HUMAN SECURITY FOR ROHINGYA REFUGEES}

Regarding humanitarian protection for Rohingya refugees in the SKB Bireuen district, based on the human security concept that must be fulfilled as described above, there are seven components that must be fulfilled in accordance with the standards stated by UNDP. To find out whether the provision of human security has been fulfilled, it can be noted from the life of the Rohingya refugees and the treatment of the committee that handles refugees while in the shelter.

a) Political Security for Rohingya Refugees In the SKB Bireuen

In 2009, ASEAN agreed to establish a regional human rights commission to promote and protect human rights and fundamental freedoms. The ASEAN Intergovernmental Commission on Human Rights (AICHR) is the realization of ASEAN leaders' commitment to coordinate, actively participate, and contribute to the application, promotion, and protection of human rights, as indicated in the first purpose of AICHR under its Terms of Reference (ToR) document. The document concludes fourteen mandates and functions. One is for the AICHR to actively and independently observe, evaluate, and investigate human rights practices in each ASEAN member states (Jati, 2017).

This means that Myanmar, which is also part of ASEAN, must make agreed commitments. So far, Myanmar is one of the Southeast Asian states that has both disturbed peace and violated human rights, even towards neighboring countries. Violations of political security towards the Rohingya people were blatant which caused the Rohingyas fled to other countries, including those who were accommodated at the SKB Bireuen, Indonesia.

While in SBK, political security must be fulfilled for Rohingya refugees, including those related to political repression and human rights abuses. Political security is the most important thing given at the shelter. Cases experienced by Rohingya refugees are political issues and especially abuses of human rights. During their stay in SKB, the Rohingya'shuman rights were very well protected. When in Myanmar, the Rohingya refugees have experienced torture and human rights violations in every line of their lives, whether they are living rights, speech rights, social rights, cultural rights, religious rights and so on.

b) Community Security for Rohingya Refugees In the SKB Bireuen

Community Security is an approach that centers around addressing people's fundamental needs by engaging aspects of human security, development and statebuilding paradigms. Different types of state and civil society actors from both supply and demand sides are brought together to identify the root causes of insecurity and collectively work to develop 
coordinated responsive solutions. This approach emphasizes capacity building and keenness of communities, local authorities and providers of security to address their own sources of insecurity and enables the creation of peoplecentered policy reforms at the sub-national and national levels.

In the context of protecting the community security for Rohingya refugees in the SKB, protecting the political security has been done well, especially community security in the context of inter-ethnic, religious and other identity based tensions. Rohingya refugees are given the freedom to maintain and use their identities. Nevertheless, their freedom has been limited because of their status as refugees and asylum seekers.Since Acehnese people and the Rohingya share the same religion, it created quite a conducive situationfor harmony and emotional connection (empathy) in SKB.

c) Personal Security for Rohingya Refugees In the SKB Bireuen

Personal security refers to the individual responsibility taken to mitigate the risks a person may encounter in areas prone to violence and thus act in accordance with their common sense and due diligence. The individual plays the most important role in providing personal security. A person must continuously learn to adapt their understanding and knowledge of security in accordance with their current situation and condition. The knowledge accumulated is then used to plan necessary security measures and increase security awareness to identify and minimize the risks of being exposed to dangers.

The indicators referred in personal security, especially for Rohingya refugees, include physical violence and crime. In the context of providing personal security protection for Rohingya refugees at Bireuen SKB, acts of violence that they had experienced while in Myanmar did not occur during the duration of their stay in SKB, both in personal and community spheres. The handling of Rohingya refugees is carried out with tender care. However, as explained above, the most important responsibility about personal security is themselves. In this case, based on an explanation from the committee that their nature does tend to be rough compared to the people of Aceh in general, so that it will have a negative impact on the Rohingya ethnicity in the SKB Bireuen's Environment.

"These Rohingya people are indeed rude, perhaps because of the influence of the conditions of violence that they experienced while in Myanmar, and also their conditions during the escape that sailed the sea for quite a long time. It is possible this condition changes their character to be rude. But because of this, many Acehnese do not like Rohingya refugees." (Mukhsin / volunteer, interviewed at SKB)

d) Environmental Security for Rohingya Refugees In the SKB Bireuen

Environmental security refers to the collection of issues that involves the roles played by both the environment and natural resources in providing peace and security, which includes environmental causes and drivers of conflict, environmental impacts of conflict, environmental recovery, and post-conflict peacebuilding. The scope of security and insecurity is not limited to violent conflict or its absence but includes the roots of sustainable livelihoods, health, 
and well-being. Environmental security underpins the rationale for investment in global environmental benefits, and is essential to maintain the earth's lifesupporting ecosystems generating water, food, and clean air. Reducing environmental security risks also depends fundamentally on improving resource governance and social resilience to natural resource shocks and stresses. The environment is better protected in the absence of conflict and in the presence of stable, effective governance (Ratner, 2018).

Environmental Security can be categorized as environmental degradation, resource depletion, natural disasters, pollution. The environmental conditions at SKB Bireuen for shelter are very good. Male and female refugee shelters are separated, so that it is enough to add comfort to the refugees. However, there were interesting things that were conveyed by the committee about these Rohingya refugees, the Committee said that:

"Even though a good place and a good shower have been provided, they are still lazy to take a bath and to maintain cleanliness. Sometimes they have to be forced, even to care for their own children, they are very lazy."

The statement abovecontradicts the general values of Muslims, where cleanliness is a part of the Islamic faith. The Islamic faith is not perfect or completed if someone's cleanliness is not properly maintained. The difference seen from the refugees could perhaps stem from their personal characters.

e) Health Security for Rohingya Refugees In the SKB Bireuen

Based on the health chapter of the health commission's 2003 report entitled Human security now, the links between health and human security could be identified by four influencing criteria namely a) the scale of the disease burden; b) the urgency for action; c) the scale of the impact on society; and d) the interdependencies or externalities with potential to cause ripple effects. By applying these criteria, the report concludes that the following three health challenges stand out as closely linked to human security: global communicable diseases; poverty-related threats; and violence and crisis (Rockenschaub et al., 2007)

The Health Security that must be safeguarded includes the problems of harmful contagious diseases, dangerous food, malnutrition, and absence of healthcare. While in the refugee shelter at SKB Bireuen, refugees received good health care. A special room with medical personnel was provided by Bireuen district, which was always ready to treat the Rohingya refugees.

The Rohingya refugees suffered from poor health conditions when they first arrived in April 2018. Many of them are sick because they have been stranded in the ocean for too long, without proper food and medicines. When Rohingya refugees arrived at the shelter, they were immediately treated and given good medication by medical personnel who were on guard at that time.

"They were well guarded here, the first time they came here, many of them were sick, especially fever, maybe due to taking too long in the ocean. But, since the first day of their arrival, a room for treatment has been provided here. Medical personnel come from the health department it seems. So Alhamdulillah, their health is getting better." 
f) Food Security for Rohingya Refugees In the SKB Bireuen

It is believed that there are almost two hundred definitions of food security of differing views and approaches but the broadest accepted definition is acquired from the 1996 World Food Summit. The definition states that "food security exists when all people, at all times, have physical, social and economicaccesstosufficient, safe and nutritious food which meets their dietary needs and food preferences for an activeand healthy life."

From the definition above, the term Food Security could at least be understood asbeing freefrom hunger and famine. In terms of food for the Rohingya refugees, the local committee provided it quite well, even though food was initially prepared by IOM and UNHCR in collaboration with volunteers. However, after November 2018, UNHCR and IOM stopped giving donations, so assistance for Rohingya refugees only relied from other donations from the community.

"Talking about food for Refugees, we cook with raw materials such as vegetables and rice that we get from donors and donations from surrounding communities. But in the last few months they (Rohingya refugees) began to dislike our food, and asked for their own cooking or buying food from outside. Maybe our food doesn't suit their tastes, before they ate food that we cooked because we had to, just to survive. "

g) Economic Security for Rohingya Refugees In the SKB Bireuen

Economic security is made up of basic social security, defined by access to basic needs infrastructure pertaining to health, education, dwelling, information, and social protection, as well as work-related security. The report describes seven component of work-related security namely job, representation, labor market, income, employment, work and skill reproduction security. While all seven dimensions are crucial, two are essential for basic security: income security and voice representation security. Basic security limits the impact and risks of uncertainties daily while providing safe working environment where people could belong in different groups, give equal opportunities to pursue a chosen profession and develop their capacities per the standard criteria of International Labour Organization (ILO) (ILO SocioEconomic Security Programme, n.d.).

From the economic security aspect, there are many other security bases that should be fulfilled, such as income security, representation security, labour market security, job security, work security, and skill reproduction security. Economic security requires protection of all basic security. From the observations we made, majority of the refugees escaped from the shelters (SKB Bireuen) because of economic security. Rohingya refugees have been very poor since living in Myanmar. They were not given proper education and access to economic development. Unfortunately, they experienced the same poor living conditions (unemployed) in SKB Bireuen as they did in their home country. Interesting facts were also conveyed by the committee at the Rohingya shelter:

"The reason Rohingya refugees ran away from Myanmar was not only because of political problems, but they want to look for better lives. Their main goal was Malaysia, but the Malaysian side turned them down, as did 
Thailand, even according to a statement from one of the Rohingya refugees saying that they were escorted by Thai sea soldiers, and then left to be stranded in Aceh (Indonesia). The main goal is not Indonesia but Malaysia."

Based on the facts presented, it shows that the protection of economic security is a very complex matter, although it does not rule out the need for protection from other security. However, security needs for the economy are very basic for other needs, so this is the most important thing to pay attention to. That way, other matters will also be fulfilled. For Rohingya Refugees who want a new life, they certainly hope that the fulfillment of economic security needs can be achieved. The economic security provided by the local Aceh government is at least better than their living conditions back in Myanmar. Although that is the case, they are unable to achieve economic security protection at SKB Bireuen, Aceh (Indonesia). With these conditions, it is obvious that they cannot last long in their current place and will look for new alternatives.

\section{LOSS OF THE ROLE OF UNHCR AND IOM IN HANDLING ROHINGYA REFUGEES AT THE SKB BIREUEN}

UNHCR's role concerns the protection and welfare of displaced people as a result of ill-treatment, violence-prone places, conflict or massive violations of human rights, due to its similarity to refugees in terms of the causes and consequences of their displacement and humanitarian needs (Adelman, 2001). However, in the case of handling Rohingya refugees in Bireuen District, UNHCR and IOM have stopped being involved. Based on interviews with the committee at the Rohingya refugee shelter they said that :

"Since November 2018, these two international organizations have stopped giving donations to Rohingya refugees. So for the needs of Rohingya refugees who are still left at the shelter, we obtain from society donors and others."

With regards to assistance from the International Organization of Migration (IOM), they have indeed made a statement that they will not give donations to refugees because there are limits to assistance. Their main reason is because donor countries, especially Australia and America, have reduced donations to this organization. However, IOM stressed that the organization would continue to provide assistance to refugees but was limited to only around 9,000 refugees who were registered before March 15, 2018. Therefore Rohingya refugees at Bireuen SKB were not IOM's responsibility because they arrived in April.

As a result of dissatisfaction with the protection of human security, coupled with the loss of involvement of international organizations that have been involved in handling and providing assistance to refugees, the Rohingya in SKB Bireuen look for alternatives to continue their struggle for better protection and more decent human security.

REASONS OF THE ROHINGYA REFUGEES ESCAPING AND INVOLVING FAILURE OF HUMAN SECURITY PROTECTION

Based on the facts described above, several reasons could be drawn that caused Rohingya refugees to escape from the shelter. First, from the economic factors, 
they depart from Myanmar to other countries (especially to Malaysia) to seek new life and improve their economic conditions, so that they can overcome problems such aspersistent poverty, and unemployment. However, what they got while in SKB Bireuen was not what they expected. They remain poor and remain unemployed. However, if they do become employed, they would be paid in Indonesian Rupiah, which the Rohingya refugees called it a fairly small currency (compared to the Malaysian Ringgit). This means that Indonesia is able to provide protection for human security in 5 contexts (political security, health security, environmental security, personal security andcommunity security), but failed in other very important protections, namely economic security.

"Their goal is not Indonesia.They are completely stranded to Indonesia. Their destination is Malaysia, because the currency there is bigger and many of their families are there. Here (Aceh, Indonesia) when someone invited them to work for wages, most of them did not want to, for various reasons. Besides, these (Rohingya) people are indeed lazy, our currency (Indonesia) is also said to be small. This was the basis of their escape, and based on the information (provided), they fled illegally from Indonesia to Malaysia."

This condition is exacerbated by the loss of assistance from international organizations (IOM and UNHCR), which has been known as the most concerned party for refugees around the world including the Rohingya Refugees. The hope of the change of life that they have brought since they left Myanmar has disappeared and now everything depends on them alone and the compassion of the Aceh people, who have not been very significant in providing assistance.

The second reason for their escape from SKB is the information that they will be returned to Myanmar. The reason of the Rohingyas departure from Myanmar to other countries was to seek a new life, and they did not want to return to Myanmar. Moreover, the image of violence and torture carried out by the Myanmar government is enough to traumatize them. It is better to escape rather than returned to violence and torture-prone Myanmar.

"Even though they tried to convince us, I wasn't sure. I thought they might kill us if we went there."

From this fact, it could be seen that the case of protecting humanitarian security for Rohingya refugees is a very complicated matter, because it involves many aspects of protection, ranging from aspects of political security, health security to environmental security, personal security, community security and also economic security. If one of them is problematic or not fulfilled, new problems will arise or even cases of refugees escaping could happen as seen in SKB Bireuen, Aceh Province.Furthermore, a very important point in the case of Rohingya refugees and in providing protection for Rohingya refugees is that they are not in a position to return to Myanmar, the Rohingya refugees want a new and better life and refuse to return to Myanmar.

\section{CONCLUSION}

Humanitarianism is a complex phenomenon with its own varieate history. A Commitment to Humanitarianist action (Human Security Action) should also be distinguished from a commitment to human rights, although again the two are easily associated (Muñoz \& Mitcham, 2010, pp. 11-12). 
Human Security is a matter that must be fulfilled to uphold justice for human rights. There are seven components of human security according to UNDP (2004) whose fulfillment must be the responsibility of each country's government. The seven components are economic security, food security, health security, environment security, personal security, community security, and political security (political security). The seven components must be fulfilled if complete human security is aimed to be realized. If one of them is not fulfilled, it will cause problems; the protection of human security will fail as what happened to the Rohingya refugees at SKB Bireuen.

Rohingya Refugees were stranded at Kuala Raja Beach, Bireuen Regency in April 2018. Now in April 2019, there are only 2 refugees left. Other refugees have escaped, but their whereabouts are still unknown although there is information which says that they escaped to Malaysia via illegal route.There are two reasons for their escape; first because during their stay at SKB Bireuen, human security in the context of political security, health security, environmental security, personal security, community security went well, but failed in the aspect of economic context which resulted in the fleeing of Rohingya refugees. The main objective is to get a good life in a place where all components of human security can be fulfilled properly, at least better than what has subsided while in Myanmar.

Providing protection for Rohingya refugees is not an easy thing, as thought by former Deputy Governor, Muzakkir Manaf, while giving remarks at the Rohingya refugee shelter in North Aceh. At that time, he said that "Rohingya are the same as us, share the same religious as us and even physically almost the same as us, so we will protect them. If necessary, do not go back to Myanmar, just stay in Aceh, we will provide agricultural land so that they can fulfill their own needs."

This statement is a statement that is inappropriate and lacks consideration. Accommodating refugees or immigrants for long periods of time and giving them the opportunity to enter the Acehnese community will change the socio-economic order of the Acehnese community. This change will result in a cultural, social and even economic clash within and towards the Acehnese community. If it goes on,conflict may arise which will have a negative impact on society.

Therefore, the problem of refugees and immigrants, must find other solutions to provide comfort for the entire community. We certainly do not want the shooting incident that occurred in Christchurch (New Zealand) to repeat itself in the future, especially not in Aceh. One common reason terrorists commit acts of violence is that Muslim immigrants have changed their social order. The same thing can happen if refugees are also given the opportunity to live and mingle with the local community, especially if the people in that place are still conservative and don't like changes. It does not intend to compare this case with terrorism, but only wants to convey that changes in the established social order can generate new sources of conflict within the society.

\section{REFERENCES}

Adelman, H. (2001). From refugees to forced migration: The UNHCR and human security. International Migration Review, 35, 7-32.

Bello, B. G. (2016). Critical Human Security Studies as an Approach for Investigating the Situation of Roma People in Italy. In S. Palidda (Ed.), Governance of Security 
and Ignored Insecurities in Contemporary Europe (pp. 154-155). Routledge.

Fitrah, E. (2015). Gagasan Human Security dan Kebijakan Keamanan di Indonesia. Journal Insignia, 2(1).

Helton, A. (2003). What is refugee protection? A question revisited. In N. Steiner, M. Gibney, \& G. Loescher (Eds.), Problems of Protection - the UNHCR, Refugees, and Human Rights. Routledge.

Human Rights Watch. (n.d.). Rohingya Crisis. Retrieved July 28, 2019, from https://www.hrw.org/tag/rohingya-crisis

ILO Socio-Economic Security Programme. (n.d.). Definitions: What we mean when we say "economic security." https://www.ilo.org/public/english/protection/ses/download/docs/definition.pdf

Jati, I. (2017). Comparative Study of the Roles of ASEAN and the Organization of Islamic Cooperation in Responding to the Rohingya Crisis. IKAT: The Indonesian Journal of Southeast Asian Studies, 1(1), 17-32. https://doi.org/10.22146/ikat.v1i1.27466

Juminah. (2018). Teacher's Problems in Teaching English Using 2013 Curriculum 2017 Revision at SMK Muhammadiyah 3 Banjarmasin [UIN Antasari Banjarmasin]. http://idr.uin-antasari.ac.id/10161/6/BAB III.pdf

Morand, M. (2015). Urban humanitarians: a new breed needed. In R. Mac Ginty \& J. H. Peterson (Eds.), The Routledge Companion to Humanitarian Action (p. 417). Routledge.

Muñoz, D. R., \& Mitcham, C. (2010). Humanitarianism. In Humanitarian Engineering (pp. 11-12). Morgan and Claypool Publisher.

Oscar A. Gómez, \& Gasper, D. (1994). Human Security. http://hdr.undp.org/sites/default/files/human_security_guidance_note_r-nhdrs.pdf

Ratner, B. D. (2018). Environmental security: dimensions and priorities.

Reach Out Refugee Protection Training Project. (2005). Handouts on Refugee Protection. http://www.unhcr.org/pages/4a16bb8a6.html

Rockenschaub, G., Pukkila, J., \& Profili, M. C. (Eds.). (2007). Towards health security. World Health Organization. http://www.euro.who.int/_data/assets/pdf_file/0006/78990/E90175.pdf

Sofinar, A. (2018). Khusida -middle- and Rumana -right- are two among the 79 Rohingya refugees who arrived in Bireuen, Aceh. They left Myanmar earlier in April to find peace outside of the country. UNHCR Indonesia. https://www.unhcr.org/id/11520-indonesian-fishermen-rescuerohingya.html/khusida-middle-and-rumana-right-are-two-among-the-79-rohingyarefugees-who-arrived-in-bireuen-aceh-they-left-myanmar-earlier-in-april-to-findpeace-outside-of-the-country-unhcr-ardi-sofinar 
Srikandini, A. G. (2011). Responsibility to Protect in Myanmar: The Political Willingness of the Myanmar Government After Cyclone Nargis. Institute of International Studies.

Thomas, C. (2001). Global governance, development and human security: exploring the links. Third World Quarterly, 22(2), 159-175. https://doi.org/10.1080/01436590120037018

United Nations General Assembly (UNGA). (1994). Note on International Protection 1994, A/AC.96/830. Author. 